\title{
ANALISIS PENGGUNAAN APLIKASI BEETALK SEBAGAI ALAT TRANSAKSI SEKSUAL DIKOTA MAKASSAR
}

\author{
Yusy Rifah Halid ${ }^{1}$ \\ Prodi. Komunikasi dan Penyiaran Islam, Institut Agama Islam Negeri Kendari \\ Email: yusyrifah@gmail.com
}

\begin{abstract}
ABSTRAK
Penelitian ini bertujuan mengetahui dan mengategorisasi (1) pola komunikasi yang digunakan dalam melakukan transaksi seksual melalui aplikasi BeeTalk ; (2) bentuk transaksi seksual yang dilakukan melalui aplikasi BeeTalk, dan (3) motivasi para pelaku menggunakan aplikasi BeeTalk untuk melakukan transaksi seksual. Penelitian ini menggunakan metode deskriptif kualitatif. Penelitian ini dilaksanakan di kota Makassar. Namun beberapa informan ada yang tersebar dibeberapa kota. Jenis dan sumber data yang digunakan adalah data primer dan data sekunder. Data primer atau data utama berupa hasil wawancara dengan informan dan data sekunder atau data pendukung berupa buku, desertasi, jurnal tesis, dan internet. Informan terdiri dari enam orang. Data yang dikumpulkan berupa hasil dari wawancara dengan para informan. Data dianalisis menggunakan beberapa teori. Hasil penelitian menunjukan bahwa (1) Pola komunikasi dalam transaksi prostitusi menggunakan aplikasi BeeTalk padaumumnya sama dengan transaksi prostitusi menggunakan aplikasi lain yang menggunakan pola komunikasi primer, sekunder dan sirkular ; (2) Praktik prostitusi tidak hanya dilakukan dengan berhubungan intim, tapi juga ada bentuk-bentuk prostitusi lain yang dilakukan secara online seperti Video Call Sex (VCS) dan Phone Sex (PS). Bahkan dalam penelitian ditemukan pula praktik penipuan berkedok prostitusi yang dilakukan secara online menggunakan aplikasi BeeTalk; (3) Landasan ekonomi, dan pemuas nafsu menjadi motivasi utama para pelaku prostitusi yang didukung oleh fitur-fitur canggih yang ada pada aplikasi BeeTalk.
\end{abstract}

Kata Kunci: Aplikasi, beetalk, Seksual, Makassar

\section{OF USE OF BEETALK APPLICATION AS A SEXUAL TRANSACTION TOOLS IN MAKASSAR DIKOTA}

\begin{abstract}
This study aims to know and categorize (1) communication patterns used in conducting sexual transactions through the BeeTalk application; (2) the form of sexual transactions made through the BeeTalk application, and (3) the motivation of the perpetrators using BeeTalk applications to conduct sexual transactions. This study used descriptive qualitative method. This research was conducted in Makassar city. However, some informants are scattered in several cities. The types and sources of data used are primary and secondary data. Primary data or main data in the form of interviews with informants and secondary data or supporting data in the form of books, desertation, thesis journal, and internet. The informant consisted of six people. The data collected is the result of interviews with informants. Data were analyzed using several theories. The result of the research indicates that (1) communication pattern in prostitution transaction using BeeTalk application in common with prostitution transaction using other application using primary, secondary and circular communication pattern; (2) The practice of prostitution is not only done by having sex, but there are also other forms of prostitution conducted online such as Video Call Sex (VCS) and Phone Sex (PS). Even in the study also found the practice of prostitution under the guise of prostitution made online using the BeeTalk application; (3) The economic basis, and the passionate lust becomes the main motivation of prostitutes who are supported by the advanced features of the BeeTalk application..
\end{abstract}

Keywords: Application, Beetalk, Sexual, Makassar 
Korespondensi: Yusy Rifah Halid, S.Kom., M.I.Kom. Prodi. Komunikasi dan Penyiaran Islam, Institut Agama Islam Negeri Kendari Alamat: Jl. Sultan Qaimuddin No.17, Baruga, Kota Kendari, Sulawesi Tenggara 93563. No. 089541087031, WhatsApp: 081355529992 Email: yusyrifah@ gmail.com

\section{PENDAHULUAN}

Penyalahgunaan media teknologi informasi ini untuk kejahatan eksploitasi diatur dalam undang undang Pasal 27 ayat 1 yang berisi setiap orang yang dengan sengaja dan tanpa hak mendistribusikan atau mentransmisikan membuat dapat diaksesnya informasi elektronik dokunmen elektronik yang memiliki muatan dalam melanggar kesusilaan dan 52 Undang - Undang No.11 tahun 2008 tentang Informasi dan Transaksi Elektronik. Sebenarnya perdagangan manusia bukanlah hal yang baru, namun beberapa tahun belakangan ini masalah ini mulai muncul kepermukaan dan menjadi perhatian khalayak

Di kota Makassar kegiatan prostitusi yang dilakukan secara online menjadi sesuatu yang tidak tabuh lagi untuk di bicarakan. Para pelaku prostitusi ini tidak mau ketinggalan kesempatan untuk memanfaatkan perkembangan tekhnologi.

Dengan kemudahan yang di tawarkan tekhnologi, kegiatan asusila dan transaksi prostitusi menjadi berbagai beragam. Tidak hanya menjajakan tubuh secara fisik namun juga bisa di lakukan secara visual melalui gambar, video, bahkan hanya dengan suara. Banyaknya aplikasi-aplikasi media sosial dengan fiturfitur tertentu bisa sangat memudahkan mereka dalam melancarkan aksinya. Line, WhatsApp, BeeTalk, Wechat, Facebook, Twitter, dan masih banyak lagi jenis aplikasi yang kerap menjadi alat transaksi prostitusi. Namun dalam penelitian ini penulis hanya fokus pada penggunaan aplikasi BeeTalk sebagai media yang masih terbilang baru yg di gunakan untuk melakukan transaksi prostitusi secara online.

Media sosial memberi ruang gerak tersendiri bagi siapa saja yang ingin mengeksplor diri mereka baik itu sekedar bersenang-senang, mencari dan berbagi informasi, hingga untuk menjadikannya lahan bisnis yang mampu meraup pundi-pundi keuntungan.

Aplikasi media sosial yang sangat beragam saat ini memungkinkan setiap orang untuk memiliki lebih dari satu media sosial dalam smart phone atau gadget mereka. Salahsatu aplikasi media sosial yang akan penulis bahas lebih lanjut adalah aplikasi BeeTalk. Aplikasi BeeTalk hanya sebagian kecil dari sekian banyak aplikasi media sosial yang ada saat ini. Media sosial memang memiliki manfaat yang sangat banyak, mulai dari kemudahan untuk mendapatkan berita atau informasi terbaru, bertemu dengan orang - orang baru atau bahkan dengan teman lama, ataupun mendapatkan teman atau kenalan baru dengan ketertarikan yang sama (Iryani $2015: 128)$.

BeeTalk adalah aplikasi media sosial mobile berbasis GPS (Global Positioning System). Hampir sama dengan aplikasi media sosial lainnya, dalam tujuan pembuatannya, aplikasi BeeTalk diperuntukkan untukmenghubungkan seseorang dengan orang lain. BeeTalk dapat dengan mudah diunduh secara gratis pada smartphone atau gadget, kita hanya perlu memastikan jaringan pada smartphone atau gadget dalam kondisi yang baik. Bagaimana cara kerja BeeTalk ? yaitu mendeteksi perangkat terdekat lainnya dengan system GPS, sehingga pengguna BeeTalk dapat mengetahui siapa saja yang menggunakan aplikasi BeeTalk di sekitarnya. 


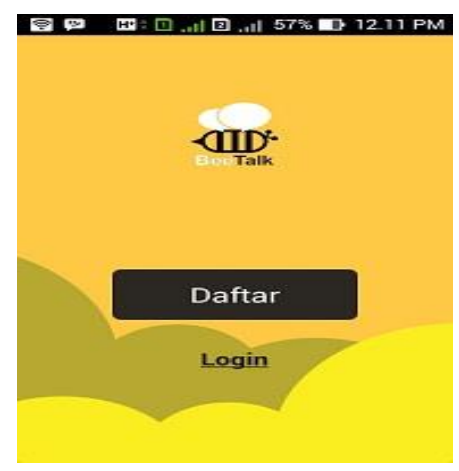

\section{Gambar 1. Tampilan Awal BeeTalk \\ Sumber : Smartphone PribadiPeneliti}

Pada gambar 1 menunjukan tampilan awal BeeTalk. Sama dengan aplikasi media sosial kebanyakan, kita diharuskan melakukan registrasi dengan memasukkan beberapa data diri yang dibutuhkan seperti e-mail, nomor telpon, kota asal, dan sebagainya. Ketika memasukkan nomor telpon, BeeTalk bisa langsung melacak siapa saja teman yang menggunakan BeeTalk pada kontak telpon anda.

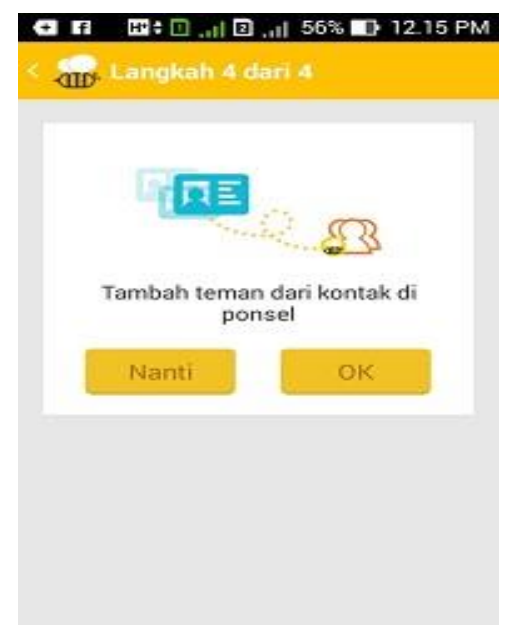

\section{Gambar 2. Sinkronisasi Kontak Telpon yang Menggunakan BeeTalk} Sumber : Smartphone PribadiPeneliti

Kegunaan BeeTalk sendiri tergantung pada siapa, dan apa yang menjadi tujuan masing-masing orang yang menggunakannya. Tujuan yang berbeda, maka akan berbeda pula hasil yang akan mereka dapatkan. Dalam penelitian ini, penulis mengkhususkan pada mereka yang menggunakan media BeeTalk sebagai alat transaksi seksual sesuai dengan judul dari penelitian ini yaitu "ANALISIS PENGGUNAAN APLIKASI BEETALK SEBAGAI ALAT TRANSAKSI SEKSUAL DI KOTA MAKASSAR” .

\section{METODE PENELITIAN}

Dalam penelitian ini penulis menggunakan tipe analisis deskripsi kualitatif empiric yang menganalisis data-data secara interpretasi kualitatif dari perolehan fakta penelitian lapangan dan menghasilkan data berupa kata (percakapan) atau lisan dari orang-orang atau perilaku yang dapat diamati. Pada hakikatnya penelitian deskriptif kualitatif adalah suatu metode dalam meneliti status sekelompok manusia, suatu objek dengan tujuan membuat deskriptif, gambaran atau lukisan secara sistematis, faktual dan akurat mengenai fakta-fakta atau fenomena yang diselidiki. 
Deskriptif empirik dimaksud upaya yang dilakukan dengan sengaja dalam rangka mencatat, melukiskan, menguraikan, melaporkan dan mempelajari tentang bagimana BeeTalk dijadikan sebagai tempat transaksi seks berlangsung. Data yang diperoleh melalui observasi partisipatif, fidnote, dan wawancara mendalam. Selain itu penelitian ini juga akan dilakukan langsung menggunakan aplikasi BeeTalk yang menjadi tempat transaksi berlangsung.

Informan

Mengenai pemilihan informan pada penelitian adalah informan yang dipilih secara purposive. Penetapan informan ini berdasarkan pada tujuan penelitian dengan kriteria bahwa informan adalah PSK yang menjadikan aplikasi BeeTalk sebagai media transaksi prostitusi, dan para "pelanggan" yang juga pernah menggunakan aplikasi BeeTalk sebagai alat transaksi prostitusi. Informan berusia 23 - 30 tahun, yaitu usia dewasa untuk laki-laki dan perempuan.

Berikut adalah profil informan, dan untuk menjaga privasi penulis menggunakan inisial dari nama beberapa informan

Tabel 1. Profil Informan

\begin{tabular}{|c|c|c|c|c|}
\hline No & Inisial & $\begin{array}{c}\text { Umur } \\
\text { (Tahun) }\end{array}$ & Pekerjaan & Domisili \\
\hline 1 & "DD" & 28 & Karyawan Swasta & Bone \\
\hline 2 & "MU" & 30 & Mahasiswa & Jakarta \\
\hline 3 & Randy Cahyadi & 27 & Wiraswasta & Makassar \\
\hline 4 & AKP.Arham Gusdiar & 29 & Anggota Polisi & Makassar \\
\hline 5 & "AY" & 23 & Mahasiswa & Makassar \\
\hline 6 & "DK" & 30 & Karyawan Perbankan & Makassar \\
\hline
\end{tabular}

\section{HASIL DAN PEMBAHASAN}

\section{Pola komunikasi yang digunakan dalam melakukan transaksi seksual melalui aplikasi BeeTalk}

\section{1) Pola Komunikasi Primer \& Sekunder}

Pola komunikasi pertama yang digunakan adalah gabungan pola komunikasi Primer \& Sekunder. Dimana proses penyampaian pikiran oleh komunikator kepada komunikan dengan menggunakan suatu simbol verbal dan non verbal melalui fitur profil yang ada pada aplikasi Beetalk sebagai Pola Komunikasi Sekunder.

Penulis akan menggambarkan bagaimana langkah-langkahnya dalam melakukan transaksi prostitusi dan berikut juga akan di lampirkan contoh transaksi melalui aplikasi BeeTalk yang peneliti dapatkan dari informan.

Mula-mula pelanggan akan mencari PSK menggunakan Fitur "Lihat Sekitar" yang ada di BeeTalk. Pelanggan kemudian bisa memilih yang berada di sekitar lokasi pelanggan berdasarkan jenis kelamin dan usia atau berdasarkan foto profil melalui menu "Flip". 


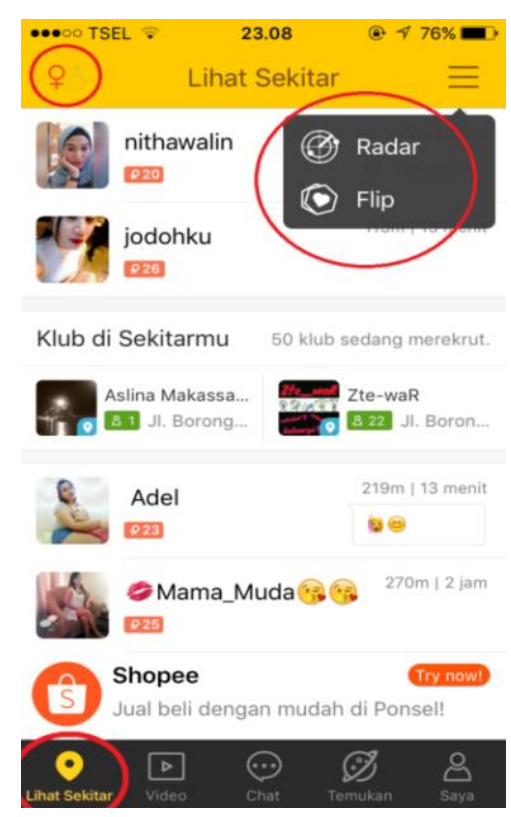

\section{Gambar 3. Pencarian dengan Fitur "Lihat Sekitar"}

Sumber : Smartphone PribadiPeneliti

Berdasarkan pengakuan beberapa informan, biasanya para PSK akan menuliskan sebuah kode pada kolom "Pesan Statusmu" untuk memberi sinyal kepada pelanggan seperti misalnya kode "Open BO" atau menuliskan nomor telpon yang bisa. Beberapa profil dibawah ini sebagai contoh pengguna yang bisa di curigai sebagai PSK dan yang bukan PSK.

Dari gambar 3 dibawah ini, dapat dilihat bahwa seorang pengguna BeeTalk berinisial "AN" memasang beberapa foto profil berpose menggoda dengan pakaian yang sedikit terbuka. Tapi itu belum cukup membuktikan bahwa ia adalah seorang PSK. Namun pada kolom Pesan Status, ia menuliskan "BO kha", yang berarti ia terang-terangan mengakui bahwa ia seorang PSK.

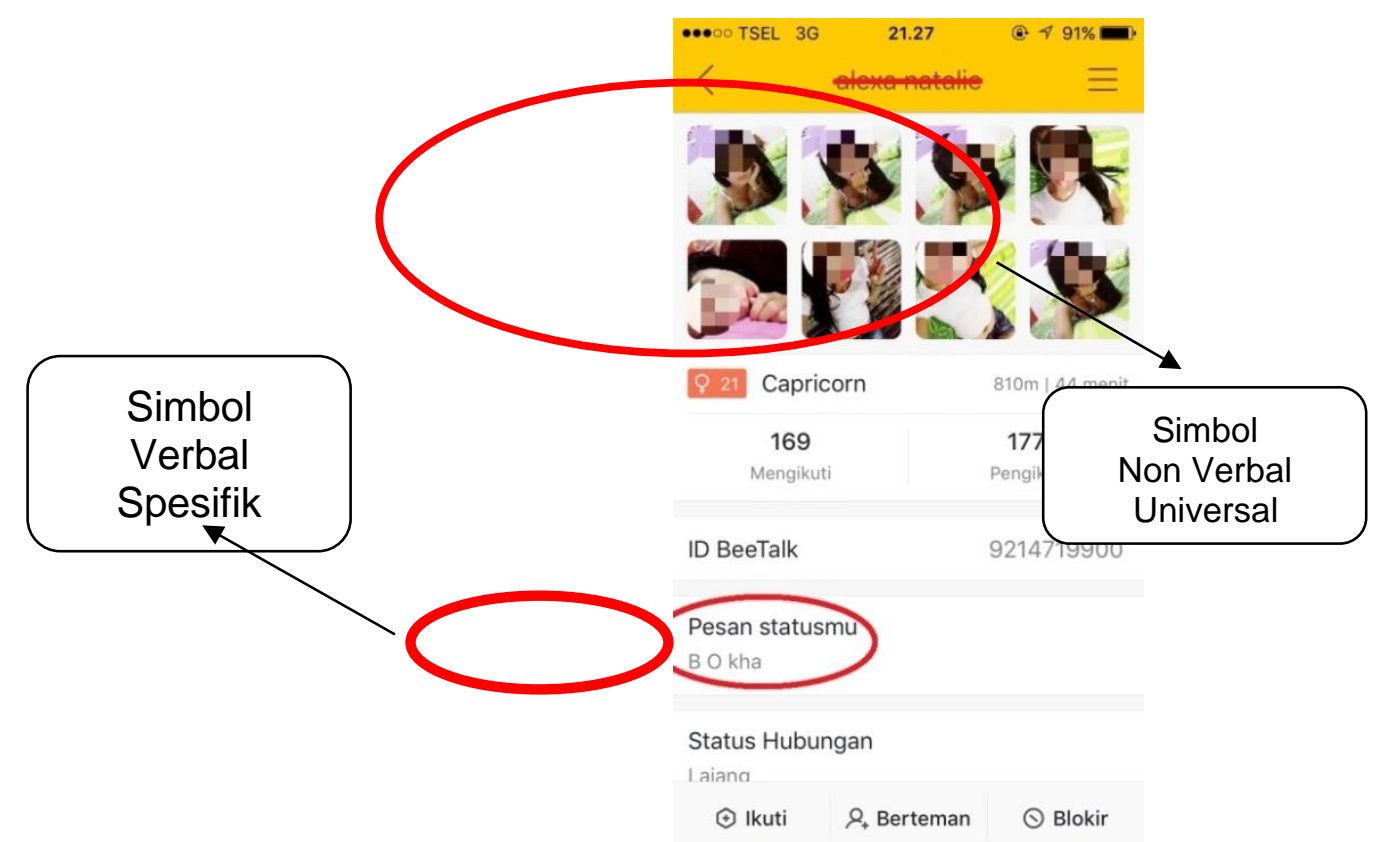

Gambar 4. Profil Pengguna BeeTalk (1)

(Pola Komunikasi Primer)

Sumber : Smartphone PribadiPeneliti 
Hampir sama dengan "AN", pengguna BeeTalk inisial "AM” juga memasang beberapa foto profil dengan pose menggoda dan pakaian terbuka dengan menonjolkan salahsatu bagian tubuh yang bisa mengindikasikan bahwa ia seorang PSK, tapi itu saja belum cukup. Pada kolom status, "AN” juga menuliskan nomor telpon Whatsapp dan itupun belum bisa membuktikan bahwa ia adalah seorang PSK.

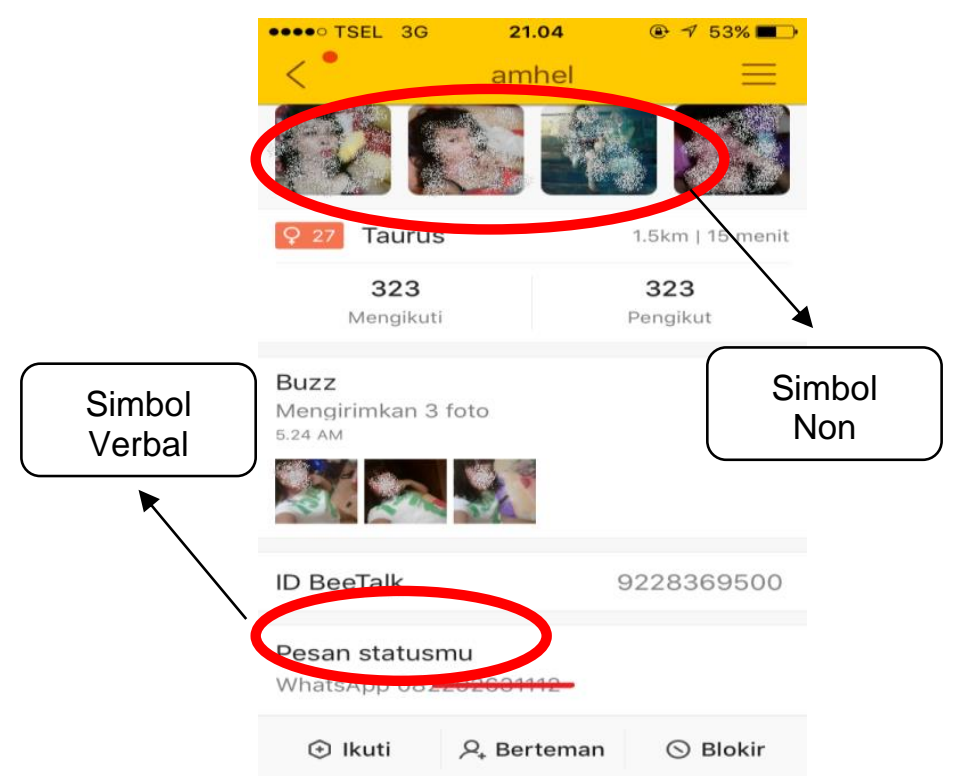

\section{Gambar 5 . Profil Pengguna BeeTalk (2) \\ (Pola Komunikasi Primer) \\ Sumber : Smartphone PribadiPeneliti}

Beda lagi dengan "PT" pada gambar 5 terlihat bahwa "PT memasang beberapa foto profil dengan pose yang tampak biasa saja, tapi mengisi kolom "Pesan Status" dengan menuliskan nomor telpon Whatsapp. Secara awam bila dilihat profil "PT" tampak biasa saja. Tapi bila dilihat lagi pengakuan beberapa informan mengenai pesan status yang berisi nomor telepon, "PT" bisa di curigai sebagai PSK.

Profil berikutnya adalah "NT". Pada profil "NT" memasang beberapa foto dengan menggunakan hijab, dan pada kolom pesan status "NT" menuliskan kata-kata yang religus. Dilahat dari foto dan pesan status tidak ada tanda-tanda bahwa "NT" adalah seorang PSK.

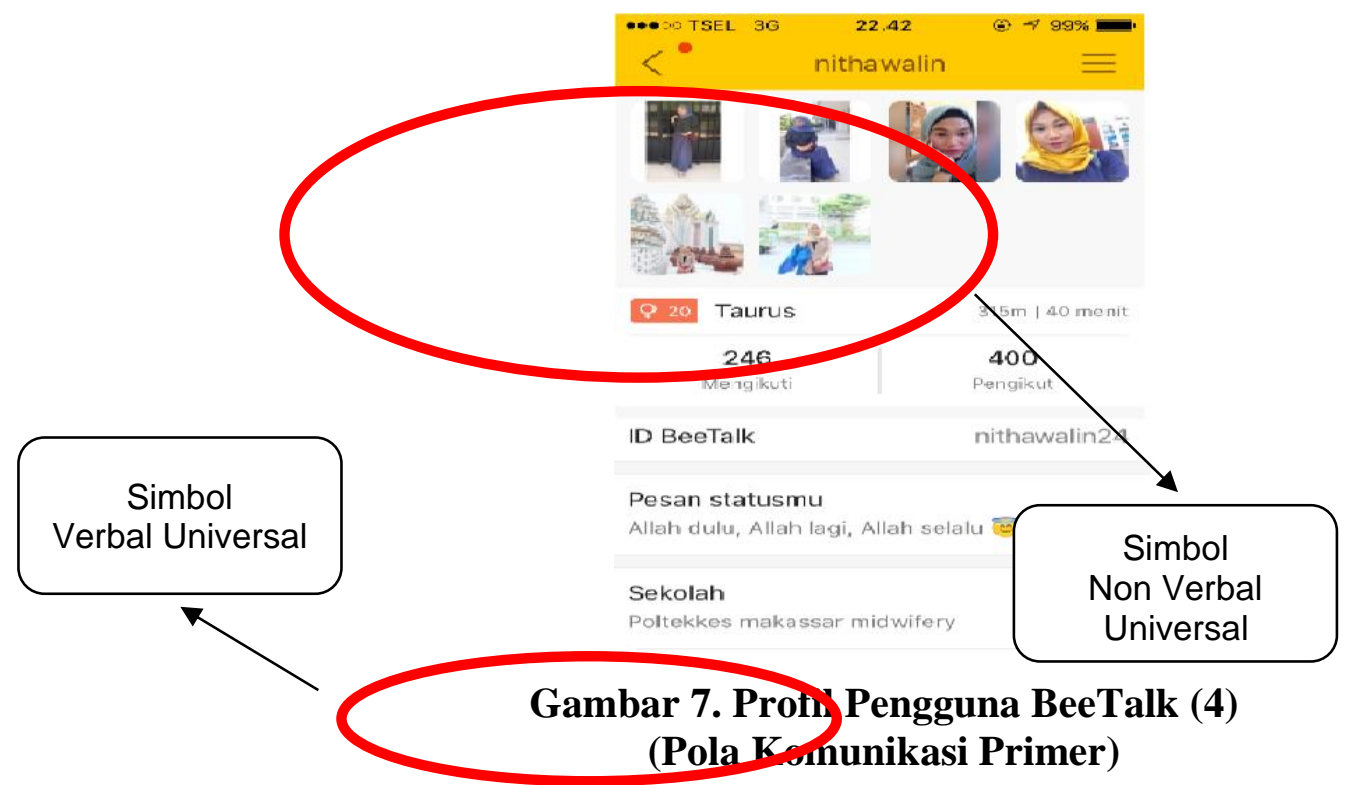




\section{Sumber : Smartphone PribadiPeneliti}

Dari beberapa contoh profil pengguna BeeTalk diatas, maka peneliti membuat pemetaan mengenai Pola Komunikasi Primer dengan symbol verbal dan non verbal yang peneliti temukan sebagai berikut:

Tabel 2. Simbol Komunikasi Verbal \& Non Verbal dilihat dari Profil Pengguna Aplikasi BeeTalk

\begin{tabular}{|c|c|c|c|c|}
\hline \multicolumn{5}{|c|}{$\begin{array}{c}\text { Pola Komunikasi Primer \& Sekunder } \\
\text { Simbol Komunikasi Verbal \& Non Verbal } \\
\text { dilihat dari Profil Pengguna Aplikasi BeeTalk }\end{array}$} \\
\hline No & Pesan Status \& Foto & Simbol & $\begin{array}{l}\text { Makna \& } \\
\text { Deskripsi }\end{array}$ & Kesimpulan \\
\hline \multirow[b]{2}{*}{1} & "BO kha" & $\begin{array}{l}\text { Verbal } \\
\text { Spesifik }\end{array}$ & $\begin{array}{l}\text { Kode yang basa di } \\
\text { gunakan untuk } \\
\text { istilah "Booking } \\
\text { Order" }\end{array}$ & PSK \\
\hline & & $\begin{array}{c}\text { Non } \\
\text { Verbal } \\
\text { Universal }\end{array}$ & $\begin{array}{l}\text { Pose menggoda } \\
\text { dengan pakaian } \\
\text { yang sedikit } \\
\text { terbuka dan } \\
\text { menonjolkan } \\
\text { salahsatu bagian } \\
\text { tubuh }\end{array}$ & $\begin{array}{l}\text { Belum Tentu } \\
\text { PSK }\end{array}$ \\
\hline \multirow[t]{2}{*}{2} & Wa $082 * * * * * * * *$ & $\begin{array}{l}\text { Verbal } \\
\text { Universal }\end{array}$ & $\begin{array}{l}\text { Mengharap untuk } \\
\text { di hubungi. } \\
\text { (Berdasarkan } \\
\text { keterangan } \\
\text { beberapa informan, } \\
\text { yang } \\
\text { mencantumkan } \\
\text { nomor telepon } \\
\text { biasanya PSK) }\end{array}$ & $\begin{array}{l}\text { Belum Tentu } \\
\text { PSK }\end{array}$ \\
\hline & $x$ & $\begin{array}{c}\text { Non } \\
\text { Verbal } \\
\text { Universal }\end{array}$ & $\begin{array}{c}\text { Pose menggoda } \\
\text { dengan pakaian } \\
\text { yang sedikit } \\
\text { terbuka dan } \\
\text { menonjolkan } \\
\text { salahsatu bagian } \\
\text { tubuh }\end{array}$ & $\begin{array}{l}\text { Belum Tentu } \\
\text { PSK }\end{array}$ \\
\hline \multirow[t]{2}{*}{3} & $\mathrm{Wa} 082 * * * * * * * * *$ & $\begin{array}{l}\text { Verbal } \\
\text { Universal }\end{array}$ & $\begin{array}{l}\text { Mengharap untuk } \\
\text { di hubungi. } \\
\text { (Berdasarkan } \\
\text { keterangan } \\
\text { beberapa informan, } \\
\text { yang } \\
\text { mencantumkan } \\
\text { nomor telepon } \\
\text { biasanya PSK) }\end{array}$ & $\begin{array}{l}\text { Belum Tentu } \\
\text { PSK }\end{array}$ \\
\hline & a) & $\begin{array}{c}\text { Non } \\
\text { Verbal } \\
\text { Universal }\end{array}$ & Pose biasa saja & $\begin{array}{l}\text { Belum Tentu } \\
\text { PSK }\end{array}$ \\
\hline
\end{tabular}




\begin{tabular}{|c|c|c|c|c|}
\hline & $\begin{array}{l}\text { Allah dulu, Allah lagi, } \\
\text { Allah selalu }\end{array}$ & $\begin{array}{l}\text { Verbal } \\
\text { Universal }\end{array}$ & Religius & Bukan PSK \\
\hline 4 & 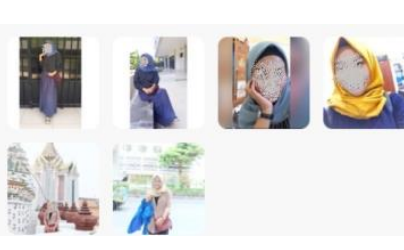 & $\begin{array}{c}\text { Non } \\
\text { Verbal } \\
\text { Universal }\end{array}$ & $\begin{array}{l}\text { Pose menggunakan } \\
\text { pakaian yang } \\
\text { mencerminkan } \\
\text { seorang yang } \\
\text { religius }\end{array}$ & Bukan PSK \\
\hline
\end{tabular}

Pada table 2 diatas merupakan pemetaan symbol komunikasi verbal dan non verbal dilihat dari profil pengguna aplikasi BeeTalk, dimana tergantung para pelanggan menentukan pilihan dan membuktikan sendiri mana yang bekerja sebagai PSK dan mana yang bukan PSK. Dengan meng-add ( memngajukan permintaan pertemanan ) dan mengirimkan pesan atau langsung menghubungi nomor telfon yang mungkin tertera pada kolom "Pesan Status".

\section{2) Pola Komunikasi Sirkular}

Langkah selanjutnya dari proses transaksi prostitusi menggunakan aplikasi BeeTalk adalah, setelah permintaan pertemanan telah di terima, pelanggan bisa langsung memulai perbincangan dan melakukan transaksi di menu "chat" yang merupakan pola komunikasi sirkular

. Berikut ini adalah contoh percakapan transaksi prostitusi yang di lakukan via BeeTalk yang peneliti dapatkan dari hasil pencarian peneliti sendiri menggunakan akun palsu yang peneliti buat dengan penyamaran sebagai seorang pelanggan.

Dari transaksi yang sudah dijelaskan diatas dari tahap awal hingga mencapai kesepakatan, maka penulis menggambarkan gabungan pola komunikasi tersebut sebagai berikut:

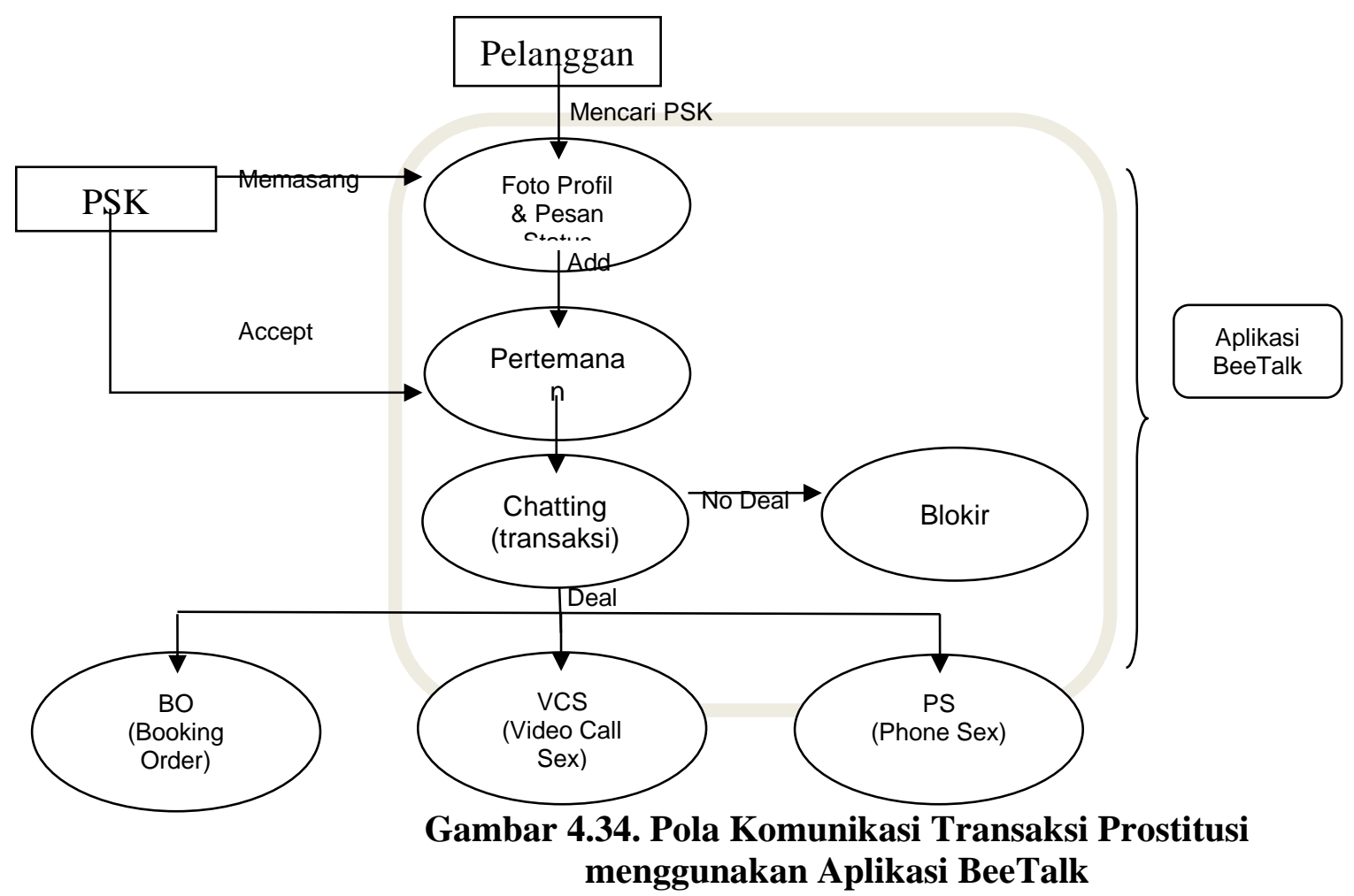




\section{Bentuk transaksi seksual yang dilakukan melalui aplikasi BeeTalk}

Transaksi prostitusi banyak jenisnya. Begitupula transaksi prostitusi yang di lakukan secara online khususnya menggunakan aplikasi BeeTalk. Dari informasi yang peneliti dapatkan dari beberapa informan mengatakan bahwa diaplikasi BeeTalk para PSK tidak hanya menjual 1jasa saja melainkan ada beberapa tawaran jasa.

\section{a. Booking $\operatorname{Order}(\mathrm{BO})$}

Bentuk transaksi ini yang paling popular terjadi diaplikasi Beetalk. Setelah melakukan transaksi melalui aplikasi BeeTalk, pelanggan dan PSK akan berjanji untuk bertemu disuatu tempat yang sudah ditentukan untuk melakukan hubungan yang lebih intim.

\section{b. Video Call Sex (VCS)}

Bentuk transaksi berikutnya adalah Video Call Sex (VCS), dimana para pelanggan dan PSK berkomunikasi dengan menampilkan aksi pornografi melalui video secara live. Aplikasi BeeTalk tidak memiliki fitur Video Call, ini di anggap sebagai salah satu kekurangan dari aplikasi tersebut. Setelah melakukan penawaran harga melalui chatting diaplikasi BeeTalk, para PSK biasanya akan mengarahkan pelanggan untuk berkomunikasi dengan media lain yang memiliki fitur Video Call seperti Whatsapp, Line, dll. Berikut adalah contoh videocall menggunakan aplikasi Line.

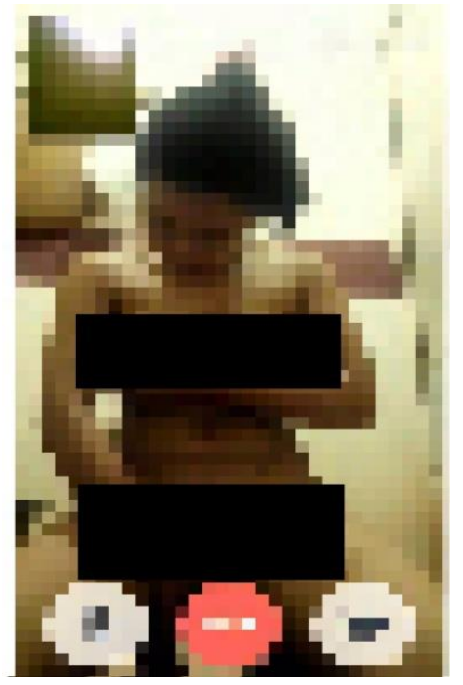

Gambar 4.35. Videocall via aplikasi Line Sumber : https://twitter.com/carcarina69/status/681128420013572096

\section{c. Phone Sex (PS)}

Bentuk transaksi yang berikutnya adalah Phone Sex, dimana para pelanggan dan PSK melakukan berkomunikasi seksual melalui telepon dengan memperdengarkan suara-suara seolah-olah sedang melakukan hubungan intim.

Berdasarkan hasil wawancara dengan informan, peneliti akan menggambarkan bentuk transaksi yang dilakukan informan seperti berikut: 


\section{Tabel 3. Bentuk Transaksi}

\begin{tabular}{|c|c|c|c|}
\hline No & Informan & & Bentuk Transaksi \\
\hline 1. & "DD” & $\mathrm{BO}$ & $\begin{array}{c}\text { Bertemu dengan PSK dan melakukan hubungan yang lebih intim di } \\
\text { sebuah hotel di Kota Makassar }\end{array}$ \\
\hline 2. & "MU" & $\mathrm{BO}, \mathrm{VCS}$ & $\begin{array}{l}\text { 1. Bertemu dengan PSK dan melakukan hubungan yang lebih intim } \\
\text { di sebuah hotel di Kota Makassar } \\
\text { 2. Melakukan adegan seksual melalui Video Call dengan Pelanggan }\end{array}$ \\
\hline 3. & Randy Cahyadi & $\mathrm{BO}$ & $\begin{array}{c}\text { Bertemu dengan PSK dan melakukan hubungan yang lebih intim di } \\
\text { sebuah hotel di Kota Makassar }\end{array}$ \\
\hline 4. & AKP.Arham Gusdiar & $\mathrm{BO}$ & $\begin{array}{c}\text { Bertemu dengan PSK dan melakukan hubungan yang lebih intim di } \\
\text { sebuah hotel di Kota Makassar }\end{array}$ \\
\hline 5. & "AY" & $\mathrm{BO}, \mathrm{VC}$ & $\begin{array}{l}\text { 1. Bertemu dengan Pelanggan dan melakukan hubungan yang lebih } \\
\text { intim di sebuah hotel di Kota Makassar } \\
\text { 2. Melakukan adegan seksual melalui Video Call dengan Pelanggan }\end{array}$ \\
\hline
\end{tabular}

1. Bertemu dengan Pelanggan dan melakukan hubungan yang lebih

6. "DK" BO, VC, PS intim di sebuah hotel di Kota Makassar

2. Melakukan adegan seksual melalui Video Call dengan Pelanggan

3. Memperdengarkan suara sensual melalui Telepon

\section{Motivasi para pelaku menggunakan aplikasi BeeTalk untuk melakukan transaksi seksual}

Entah dimulai sejak kapan, prostitusi online yang di lakukan melalui aplikasi BeeTalk semakin berkembang. Bahkan selama penelitian, hampir semua orang yang peneliti Tanya tentang aplikasi BeeTalk semua berfikir negative kearah prostitusi. Mungkin ini menjadi salahsatu faktor praktek prostitusi menggunakan aplikasi BeeTalk ini semakin berkembang, karena image yang sudah terlanjur terbangun di masyarakat, sehingga para pelaku menjadikannya sebagai wadah untuk "menjual" dan "membeli".

Dari hasil wawancara peneliti dengan para informan yangsudah dibahas sebelumnya, dapat peneliti simpulkan bahwa motivasi mereka menggunakan aplikasi BeeTalk sebagai alat transaksi prostitusi adalah kemudahan dalam bertransaksi. Kegiatan ini tidak lepas dari dukung fitur-fitur canggih yang ada diaplikasi BeeTalk.

Semakin canggih tekhnologinya semakin banyak cela yang bisa dimanfaatkan pengguna sebagai pendukung melakukan transaksi prostitusi secara online menggunakan aplikasi BeeTalk. Berikut ini adalah beberapa fitur dalam aplikasi BeeTalk yang menjadi pendukung praktek prostitusi terjadi.

1) Lihat Sekitar / Look Around

Fitur "Lihat Sekitar / Look Around" merupakan fitur yang paling di andalkan oleh aplikasi BeeTalk yang tidak di jumpai di aplikasi chating kebanyakan. Apalagi fitur ini di lengkapi dengan menu "Radar" dan "Flip" menjadi pelengkap dari fitur ini. Pencarian dengan menggunakan "Radar" di anggap menjadi salahsatu keunggulan aplikasi BeeTalk yang sangat membantu baik bagi PSK maupun bagi para pelanggan yang ingin 
mencari pengguna BeeTalk yang ada di sekitarnya. Terdapat pula pengaturan pencarian berdasarkan jenis kelamin dan umur. Seperti yang telah dibahas sebelumnya.
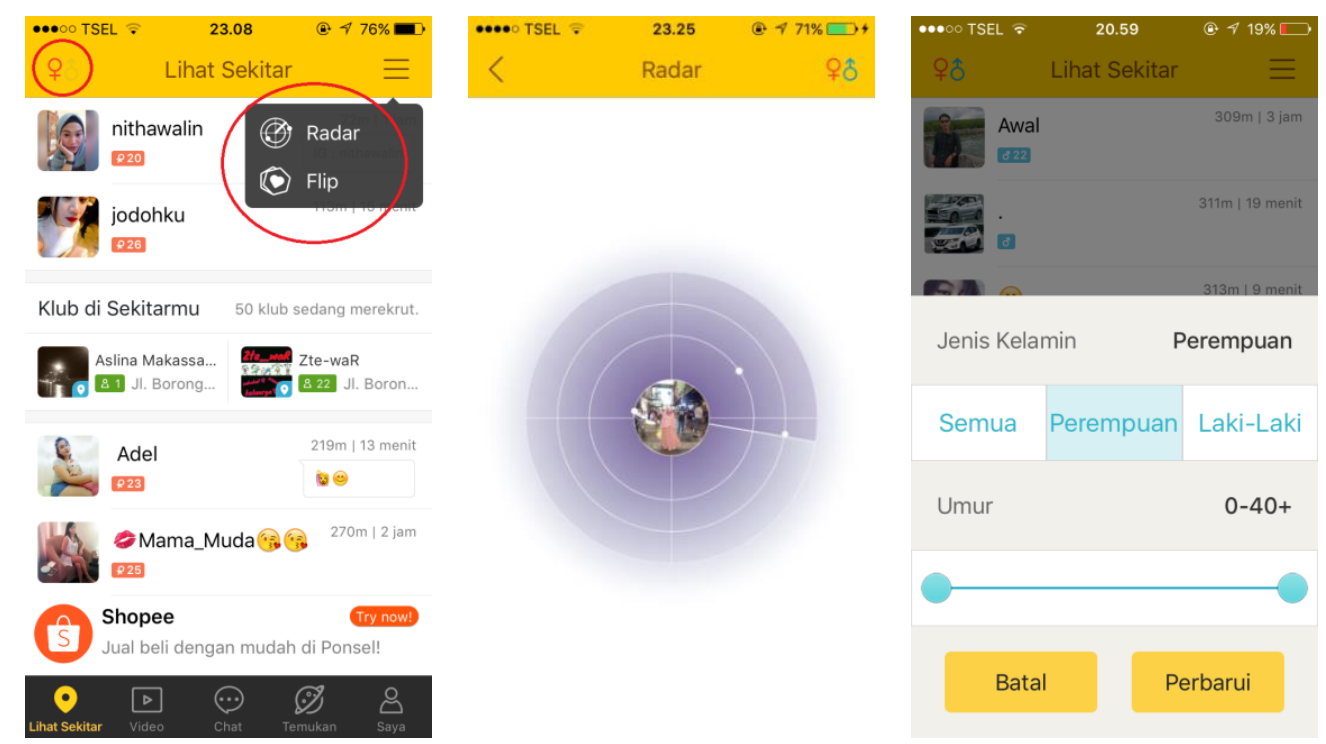

\section{Gambar 4.36 Fitur Pendukung "Lihat Sekitar / Look Around" Sumber : Smartphone PribadiPeneliti}

2) Pesan Statusmu \& Foto Profil

Telah dibahas pula sebelumnya bagaimana fitur ini sangat berperan dalam proses transaksi prostitusi diaplikasi BeeTalk. Penulisan pesan status dan penggunaan foto profil dapat menarik perhatian para pelanggan dengan mudah.
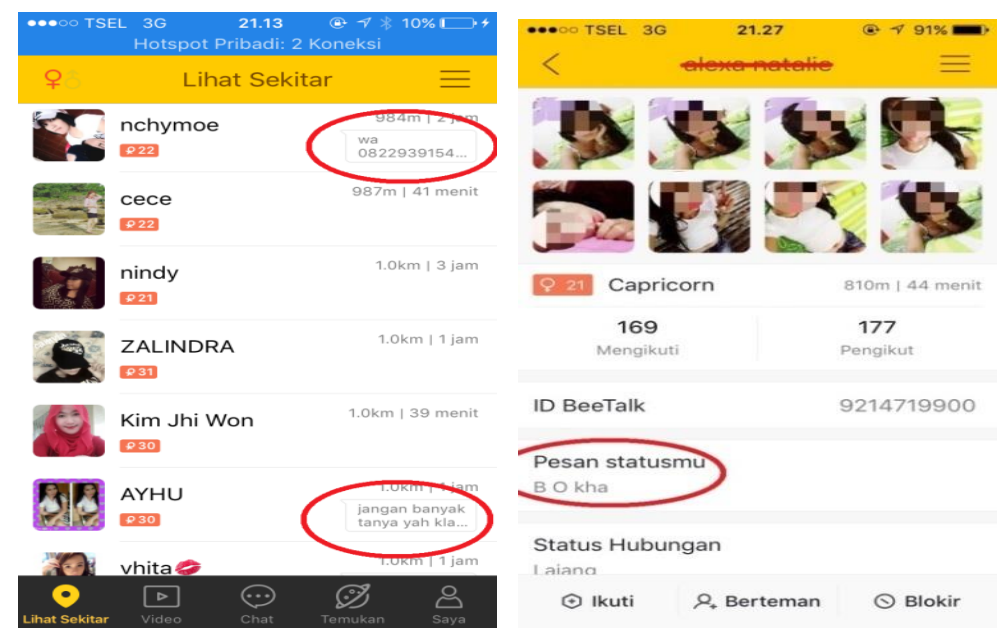

\section{Gambar 4.37 Fitur Pendukung "Pesan Status \& Foto Profil"} Sumber : Smartphone PribadiPeneliti

3) Whisper atau Bisikan

Satu hal yang membuat chatting melalui BeeTalk berbeda adalah, Anda bisa membuat pesan Anda menjadi sebuah "whisper”, yang harus diklik terlebih dahulu agar bisa dibaca, dan akan hilang dalam jangka waktu paling lama 15 detik sesuai dengan yang ditentukan pengirim. Ini membuat pengguna bisa berbagi sesuatu yang rahasia atau pribadi tanpa harus takut ketahuan jika nantinya ada orang yang iseng ingin tahu. 


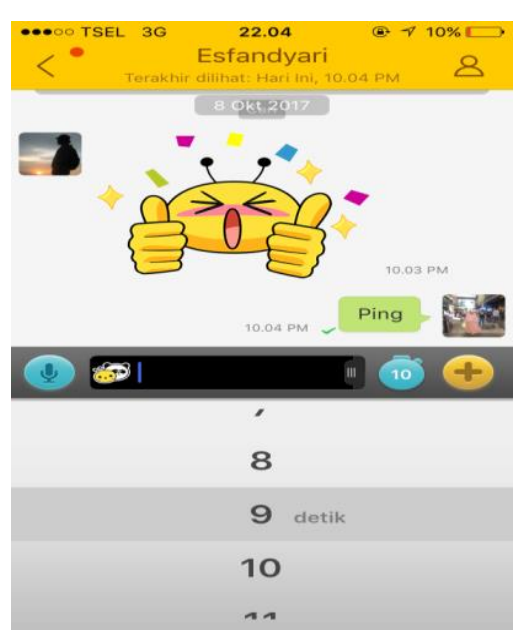

\section{Gambar 4.38 Fitur Pendukung (Whisper atau Bisikan) Sumber : Smartphone PribadiPeneliti}

4) Temukan / Discover

Dalam fitur ini terdapat forum dimana kita bisa menemukan forum diskusi berdasarkan minat dan hobi yang sama. Forum ini sering di manfaatkan baik para pelanggan maupun para PSK untuk menemukan seseorang dengan visi dan misi yang sama.

Keempat fitur yang telah disebutkan merupakan fitur yang paling membantu terjadinya transaksi prostitusi berdasarkan hasil penelitian dan pengakuan para informan.

Berikut ini adalah ringkasan mengenai bentuk transaksi dan motivasi para informan menggunakan aplikasi BeeTalk dalam melakukan transaksi prostitusi. Data-data dibawah ini merupakan hasil rangkuman dari hasil wawancara peneliti mengenai aplikasi BeeTalk.

Tabel 4.5. Motivasi menggunakan aplikasi BeeTalk sebagai alat transaksi seksual

\begin{tabular}{|c|c|c|c|c|}
\hline No & Informan & $\begin{array}{c}\text { Menggunakan } \\
\text { BeeTalk }\end{array}$ & $\begin{array}{c}\text { Motivasi Menggunakan } \\
\text { BeeTalk sebagai Alat } \\
\text { Transaaksi Prostitusi }\end{array}$ & $\begin{array}{c}\text { Alasan Berhenti } \\
\text { Menggunakan } \\
\text { BeeTalk sebagai } \\
\text { Alat Transaaksi } \\
\text { Prostitusi } \\
\end{array}$ \\
\hline 1. & "DD" & $2015-2017$ & $\begin{array}{c}\text { "Banyak PSK yang } \\
\text { menggunakan } \\
\text { sehingga mudah untuk } \\
\text { mendapatkan yang } \\
\text { bisa BO” }\end{array}$ & $\begin{array}{c}\text { Pernah tertipu foto } \\
\text { profil yang berbeda } \\
\text { dengan kenyataannya } \\
\text { saat ia bertemu secara } \\
\text { langsung }\end{array}$ \\
\hline 2. & "MU" & $2013-2016$ & $\begin{array}{c}\text { "Lebih mudah } \\
\text { mendapatkan PSK } \\
\text { karena banyak yang } \\
\text { jualan menggunakan } \\
\text { aplikasi Beetalk } \\
\text { apalagi di kota } \\
\text { Makassar" }\end{array}$ & $\begin{array}{c}\text { Pernah tertipu foto } \\
\text { profil yang berbeda } \\
\text { dengan kenyataannya } \\
\text { saat ia bertemu secara } \\
\text { langsung }\end{array}$ \\
\hline 3. & Randy Cahyadi & $\begin{array}{c}\text { Mei } 2017 \\
- \\
\text { September } 2017\end{array}$ & $\begin{array}{c}\text { Beberapa fitur } \\
\text { pendukung yang tidak } \\
\text { ada di aplikasi lain } \\
\text { yang membuat } \\
\text { aplikasi BeeTalk jadi } \\
\text { popular digunakan } \\
\text { sebagai alat transaksi }\end{array}$ & $\begin{array}{c}\text { Pernah ditipu. Setelah } \\
\text { melakukan } \\
\text { pembayaran via } \\
\text { transfer melalui atm } \\
\text { sebagai tanda jadi, } \\
\text { ternyata PSK tersebut }\end{array}$ \\
\hline
\end{tabular}




\begin{tabular}{|c|c|c|c|c|}
\hline & & & $\begin{array}{l}\text { prostitusi, sehingga } \\
\text { mudah mendapat PSK }\end{array}$ & $\begin{array}{l}\text { tidak bisa lagi } \\
\text { dihubungi }\end{array}$ \\
\hline 4. & AKP.Arham Gusdiar & 2016 & $\begin{array}{c}\text { Hanya untuk } \\
\text { keperluan } \\
\text { penyelidikan kasus } \\
\text { prostitusi yang } \\
\text { dilakukan secara } \\
\text { online }\end{array}$ & $\begin{array}{c}\text { Penyelidikan telah } \\
\text { selesai }\end{array}$ \\
\hline 5. & "AY" & $2016-2017$ & $\begin{array}{l}\text { "Mudah mendapatkan } \\
\text { pelanggan. Apalagi } \\
\text { kalau di BeeTalk bisa } \\
\text { cari yang ada disekitar } \\
\text { yang paling dekat. " }\end{array}$ & $\begin{array}{l}\text { Sudah mulai sepi } \\
\text { pelanggan }\end{array}$ \\
\hline 6. & "DK" & $2015-2017$ & $\begin{array}{c}\text { "Iya lebih mudah } \\
\text { dapat customer karena } \\
\text { mungkin sudah } \\
\text { banyak juga yang tau } \\
\text { kalau di BeeTalk itu } \\
\text { banyak yang "jualan" }\end{array}$ & $\begin{array}{c}\text { Taubat } \\
\text { (Telah kembali } \\
\text { kejalan yang benar) }\end{array}$ \\
\hline
\end{tabular}

\section{Pembahasan}

Takdapat dipungkiri bahwa perkembangan tekhnologi saat ini semakin pesat. Seiring dengan berkembangnya tekhnologi, media juga semakin berevolusi yang dibuktikan dengan munculnya berbagai aplikasi sosial media yang dapat digunakan bebas oleh masyarakat dalam menunjang keseharian mereka. Semakin banyak sosial media, semakin susah pula pengendalian penggunaannya. Beberapa media sosial bahkan hampir semua media sosial oleh oknum tertentu dimanfaatkan tidak sebagaimana mestinya.

McQuail (1996) menyatakan, bahwa dalam deskripsi tentang fungsi media kebanyakan dalam hal-hal yang bersifat positif, padahal dibalik itu terdapat hal-hal yang bersifat negative yang kadang sulit dihindari. Karena itu informasi yang disampaikan media dapat menimbulkan efek yang tidak diinginkan (disfungsi komunikasi), yang biasa disebut sebagai fungsi tersembunyi.

Keresahan akan aktivitas negatif di cyber space sangat dirasakan oleh masyarakat. Apalagi dengan beberapa pemberitaan di media massa tentang adanya prostitusi yang dilakukan secara online. Menurut John Palfrey, seorang professor ilmu hokum Harvard University yang juga direktur dari Berkman Center for Internet and Society menyatakan bahwa kegiatan prostitusi di Internet diyakini masih terus berkembang.

Kompleknya kehidupan seiring dengan perkembangan ilmu, sosial dan budaya secara tidak langsung memarakkan praktik prostitusi. Keadaan ekonomi yang mendesak dengan terbatasnya kemampuan serta persediaan lapangan pekerjaan yang tidak memadai sering menjadi alasan sebagian besar wanita yang memilih profesi sebagai PSK, di kota-kota besar seperti Makassar merupakan contoh nyata akan besarnya jumlah prostitusi, baik yang dilakukan dengan terbuka maupun terselubung memanfaatkan sosial media salahsatunya adalah BeeTalk.

BeeTalk adalah Sebuah aplikasi chatting yang dibuat oleh BeeTalk Private Ltd Developer aplikasi mobile yang berasal dari thailand. BeeTalk sendiri sudah dirilis pada tahun 2014 lalu, aplikasi chatting ini di 
garap oleh Garena yaitu sebuah penyedia platform terbesar di Asia, yang menempatkan aplikasi chatting ini menjadi populer dengan rating 4.1 di playstore serta sudah diunduh lebih dari 10.000.000 kali.

Dalam penciptaannya, aplikasi BeeTalk itu sendiri bertujuan untuk menjalin komunikasi, berkenalan dengan teman baru, mencari teman kencan hingga mencari jodoh. Ini didukung oleh beragamnya fitur-fitur menarik yang ditawarkan oleh aplikasi BeeTalk yang mungkin tidak ada diaplikasi sosial media lainnya. Namun dengan adanya aplikasi BeeTalk dengan segala fitur-fitur pendukungnya itulah, BeeTalk justru dimanfaatkan sebagai alat transaksi prostitusi. Di kota Makassar khususnya, telah banyak transaksi prostitusi yang dilakukan menggunakan aplikasi BeeTalk.

Berdasarkan hasil temuan riset yang dilakukan oleh peneliti selama kuranglebih tiga bulan, ada beberapa hal yang sangat penting untuk diketahui bersama dimana peneliti meminta bantuan kepada enam orang informan untuk memberikan informasi terkait penggunaan BeeTalk sebagai alat transaksi prostitusi, maka dapat dipetakan sebagai berikut :

1. Informan peneliti berasal dari usia 23 tahun - 30 tahun, yaitu usia dewasa pria dan wanita.

2. Informan berasal dari berbagai latar belakang profesi mulai dari mahasiswa, karyawan swasta, karyawan perbankkan yang juga seorang, kontraktor, hingga polisi.

3. Informan berasal dari kota Makassar, namun beberapa diantaranya pindah keluar kota untuk keperluan pekerjaan dan melanjutkan pendidikan.

4. Pola Komunikasi dalam transaksi prostitusi menggunakan aplikasi BeeTalk terdiri atas dua pola yaitu, Pola Komunikasi Primer Sekunder \& Pola Komunikasi Sirkular

5. Ada beberapa bentuk transaksi prostitusi yang dilakukan menggunakan aplikasi BeeTalk seperti, BO (Booking Order), VCS (Video Call Sex), PS (Phone Sex), hingga penipuan berkedok prostitusi.

6. Informan dalam menggunakan aplikasi BeeTalk memiliki peran yang berbeda, ada yang berperan sebagai PSK, pelanggan, polisi, hingga mucikari.

7. Tujuan penggunaan aplikasi BeeTalk dalam rtransaksi prostitusi berbeda berdasarkan kebutuhan dari penggunaan aplikasi itu sendiri sesuai dengan peran masing-masing.

8. Motivasi informan menggunakan aplikasi BeeTalk ditunjang oleh fitur-fitur canggih yang membuat transaksi prostitusi menjadi lebih mudah.

9. Alasan para informan tidak lagi menggunakan aplikasi BeeTalk juga beragam, ada yang menjadi korban penipuan, karena BeeTalk sudah mulai sepi pengguna, bahkan ada informan yang mengaku sudah taubat.

Temuan riset oleh peneliti diatas menunjukan bahwa ada keterkaitan yang sangat erat dengan beberapa kajian konsep yang digunakan dalam melihat dan membedah transaksi prostitusi menggunakan aplikasi BeeTalk ini.

\section{Pola Komunikasi dalam Transaksi Prostitus}


Pola komunikasi menurut Effendy, 1986 Pola Komunikasi adalah proses yang dirancang untuk mewakili kenyataan keterpautannya unsur-unsur yang di cakup beserta keberlangsunganya, guna memudahkan pemikiran secara sistematik dan logis.Komunikasi adalah salah satu bagian dari hubungan antar manusia baik individu maupun kelompok dalam kehidupan sehari-hari (Effendy, 1986) dari pengertian ini jelas bahwa Komunikasi melibatkan sejumlah orang dimana seorang menyatakan sesuatu kepada orang lain, jadi yag terlibat dalam Komunikasi itu adalah manusia itu. Pola komunikasi dibagi menjadi tiga yaitu,komunikasi satu arah, komunikasi dua arah dan komunikasi multi arah. 1) Pola Komunikasi Primer, merupakan suatu proses penyampaian pikiran oleh komunikator kepada komunikan dengan menggunakan suatu simbol sebagai media atau saluran. Dalam pola ini terbagi menjadi dua lambang yaitu lambang verbal dan lambang non verbal. 2) Pola Komunikasi Sekunder, adalah proses penyampaian pesan oleh seseorang kepada orang lain dengan menggunakan alat atau sarana sebagai media kedua setelah memakai lambang sebagai media media pertama. 3) Pola Komunikasi Linear, mengandung makna lurus yang berarti perjalanan dari satu titik ke titik lain secara lurus, yang berarti penyampaian pesan oleh komunikator kepada komunikan sebagai titik terminal. 4) Pola Komunikasi Sirkular, secara harfiah berarti bulat, bundar atau keiling. Dalam proses sirkular itu terjadinya feedback atau umpan balik, yaitu terjadinya arus dari komunikan ke komunikator, sebagai penentu utama keberhasilan komunikasi.

Teori ini bersinggungan erat dengan penemuan peneliti mengenai pola komunikasi yang digunakan dalam transaksi prostitusi menggunakan aplikasi BeeTalk dimana dalam penemuannya, peneliti mendapatkan ada tiga pola komunikasi yang digunakan yaitu pola komunikasi primer, sekunder, dan sirkular. Misalnya penggunaan foto profil dalam akun media sosial ( BeeTalk ) sebagai salahsatu fasilitas untuk menampilkan foto dalam berbagai pose sebagai bentuk ekspresi kecantikan, erotisme, enerjik, dan semua yang dapat menampilkan seluruh potensi erotisme nilai guna (use value) tubuh menuju pelayanan atau nilai tukar (exchange value), yang merupakan pola komunikasi Primer Sekunder yang dilakukan oleh para PSK. Setelah itu akan terjalin hubungan komunikasi melalui chating setelah "penjual" dan "pembeli" sepakat untuk melakukan "transaksi jual beli", kegiatan ini merupakan pola komunikasi Sirkular. Setelah kesepakatan terjalin dalam proses transaksi, akan dilanjutkan dengan proses pembayaran tergantung kesepakatan antara PSK dengan pelanggan apakah itu berbentuk uang tunai atau melalui transfer bank, hingga pembayaran menggunakan pulsa.

\section{Media Baru Melahirkan Bentuk Lain Prostitusi}

Teori media baru merupakan sebuah teori yang dikembangkan oleh Pierre Levy, yang mengemukakan bahwa media baru merupakan teori yang membahas mengenai perkembangan media. Dalam teori media baru, terdapat dua pandangan, pertama yaitu pendangan interaksi sosial, yang membedakan media menurut kedekatannya dengan interaksi tatap muka. Pierre Levy memandang World Wide Web (WWW) sebagai 
sebuah lingkungan informasi yang terbuka, fleksibel dan dinamis, yang memungkinkan manusia mengembangkan orientasi pengetahuan yang baru dan juga terlibat dalam dunia demokratis tentang pembagian mutual dan pemberian kuasa yang lebih interaktif dan berdasarkan pada masyarakat.

Meninjau hubungan penggunaan konten media baru dengan sikap seksual remaja sangat pariatif. Kecendrungan narsisme yang terdapat dalam profil setiap "partisipan" media baru masih sangat "Selective Exposure". Mereka dengan cermat memilih fasilitas media baru (BeeTalk misalnya) dengan salah satu atau beberapa konten di dalamnya untuk menonjolkan diri dan "menawarkan" berbagai bagian tubuh agar dimaknai oleh orang lain sebagai sikap meminta, menantang, dan menawarkan diri.

Jean Baudriliard mengemukakan di dalam bukunya yang berjudul seducation, bahwa kekuatan tubuh perempuan di dalam masyarakat modern terletak pada kekuatan rayuan yang dimilikinya, yaitu kemampuan untuk mengekspresikan secara bebas berbagai potensi sensual pada dirinya untuk menghasilkan daya pikat dan pesona yang besar (Jean Baudrlliard, 1990:70). Dan indicator-indikator seksualitas dalam media baru dilihat melalui beberapa aspek berikut:

Pertama, tampilan tubuh (body appearance). Seringkali di dalam media baru, khususnya BeeTalk, setiap "partisipan" menekankan diri mereka pada aspek umur, yaitu kemudaan tubuh yang di tampilkan sebagai identitas ( profil of self). Dan biasanya kemudaan perempuan mempunyai nilai sensualitas yang relative tinggi, selain bentuk tubuh yang seksi, sensual, langsing, dan tinggi merupakan modal pariatif dalam menciptakan kesan makna sensualitas.

Kedua, perilaku (manner). Perilaku merupakan aspek lain yang memperbesar daya pikat di dalam media baru, yang dapat dilihat melalui ekspresi tubuh secara visual dengan berbagai gaya, pose, ukuran, dan makna yang bervariasi seperti menantang, mempertontonkan, merayu, menggoda, mengajak, memperlihatkan gairah, menjulurkan lidah, dan dari model pakaian.

Ketiga, aktivitas tubuh (activity of body). Seseorang menampilkan dirinya sebagai pemalu atau agresif, dengan mudah dapat di lacak dari cara-cara mereka merespon berbagai hal. Misalnya perempuan yang menutup bagian dada, "masih" menunjukan ekspresi rasa malu secara sosial, perempuan yang menunjukkan ekspresi narsismenya, menunjukkan kecendrungan eksibisonisme. Overexposed body dengan menonjolkan organ-organ tubuh seperti paha, betis, sebagian payudara, dan dengan pakaian yang sangat tipis. (Gillian Dyer, 1982:97).

Fenomena eksploitasi tubuh akan semakin meluas dengan keterlibatan media baru sebagai sarana yang amat sangat bebas, tampaknya akan tercipta sebuah pola, model, gaya, dan format baru dalam dunia transaksi seksual dimasa mendatang, sehingga mengarah juga pada pembiasan (naturalization) terhadap gejala-gejala seksualitas sebagai sebuah hukum kebudayaan baru.

Fenomena ini dibuktikan dengan penemuan peneliti mengenai bentuk transaksi prostitusi yang dilakukan menggunakan aplikasi BeeTalk yang sangat beragam. Seperti BO (Booking Order) dimana PSK dan pelanggan akan bertemu dan melakukan prostitusi nyata, VCS (Video Call Sex) sebuah pemanfaatan konten 
video call untuk memperlihatkan aktivitas seksual melalui video secara live, PS (Phone Sex) dimana akan terjadi percakapan suara barbau porno grafi melalui telepon.

\section{Motif Terjadinya Praktik Prostitusi}

Semua tingkah laku manusia pada hakikatnya mempunyai motif tertentu. Motif merupakan suatu pengertian yang melingkupi semua penggerak, alasan-alsan atau dorongan-dorongan dalam diri manusia yang menyebabkan manusia berbuat sesuatu. Dalam mempelajari tingkah laku manusia pada umumnya, kita harus mengetahui apa yang dilakukan, bagaimana ia melakukan, dan mengapa ia melakukan, dengan kata lain, kita sebaiknya mengetahui know what, know how, dan know why.

Keinginan dan kebutuhan masing-masing individu berbeda dari waktu ke waktu dan dari tempat ketempat, sehingga motif juga berbeda-beda. Motif seseorang bisa bersifat tunggal, bisa juga bergabung/ ganda.

Seperti motif para informan dalam menggunakan aplikasi BeeTalk sebagai alat prostitusi, mereka menggunakan berdasarkan kebutuhan masing-masing, sebagai berikut:

a. Mencari pelampiasan nafsu

Informan pengguna aplikasi BeeTalk yang telah peneliti wawancarai yang berperan sebagai pelanggan , tujuan dalam menggunakan aplikasi BeeTalk adalah sebagai media untuk mencari seorang PSK untuk melampiaskan nafsu, baik dengan cara bertemu dan melakukan hubungan intim, sekedar atau melampiaskan nafsu melalui media video call sex atau phone sex.

b. Kebutuhan Ekonomi

Informan pengguna aplikasi BeeTalk yang telah peneliti wawancarai yang berperan sebagai PSK dan Mucikari, menjadikan media BeeTalk sebagai media mencari uang dengan cara menjual jasa prostitusi secara online menggunakan aplikasi tersebut.

c. Penipuan Berkedok Prostitusi

Temuan lain yang peneliti dapatkan dari hasil penelitian, selain praktek prostitusi itu sendiri, terdapat juga motif lain yaitu penipuan dengan menggunakan prostitusi sebagai modusnya. Ini terbukti dari hasil wawancara peneliti dengan beberapa informan yang berperan sebagai pelanggan yang mengaku telah berhenti menggunakan aplikasi BeeTalk ini sebagai alat transaksi prostitusi dikarenakan pengalaman mereka yang pernah tertipu saat melakukan transaksi prostitusi. Kejadian itupun diperkuat dengan informan "AKP.Arham Gusdiar" yang telah peneliti wawancara sebagai seorang polisi yang telah melakukan penyelidikan kasus prostitusi secara online dan juga menemukan modus penipuan berkedok prostitusi dalam penyelidikannya menggunakan aplikasi BeeTalk.

Teori Uses and Gratifications meneliti asal mula kebutuhan manusia secara psikologis dan sosial, yang menimbulkan harapan tertentu dari media masa atau sumber-sumber lain (atau keterlibatan pada kegiatan lain) dan menimbulkan pemenuhan kebutuhan penelitian yang menggunakan Uses and Gratifications model memusatkan perhatian pada kegunaan isi media untuk memperoleh gratifikasi atau pemenuhan kebutuhan. 
Teori ini pertama kali diperkenalkan oleh Herbert Blumer dan Elihu Katz (1974). Teori ini mengatakan bahwa pengguna media memainkan peran aktif untuk memilih dan menggunakan media tersebut. Dengan kata lain, pengguna media adalah pihak yang aktif dalam proses komunikasi. Pengguna media berusaha mencari sumber media yang paling baik di dalam usaha memenhi kebutuhannya. Artinya pengguna media mempunyai pilihan alternatif untuk memuaskan kebutuhannya.

Elemen dasar yang mendasari pendekatan teori ini (Karl dalam Bungin, 2007): (1) Kebutuhan dasar tertentu, dalam interaksinya dengan (2) berbagai kombinasi antara intra dan ekstra individu, dan juga dengan (3) struktur masyarakat, termasuk struktur media, menghasilkan (4) berbagai percampuran personal individu, dan (5) persepsi mengenai solusi bagi persoalan tersebut, yang menghasilkan (6) berbagai motif untuk mencari pemenuhan atau penyelesaian persoalan, yang menghasikan (7) perbedaan pola konsumsi media dan ( perbedaan pola perilaku lainnya, yang menyebabkan (9) perbedaan pola konsumsi, yang dapat memengaruhi (10) kombinasi karakteristik intra dan ekstra individu, sekaligus akan memengaruhi pula (11) struktur media dan berbagai struktur politik, kultural, dan ekonomi dalam masyarakat.

Teori Uses and Gratifications ini sangat bersinggungan erat pada semua informan dalam keputusannya memilih media BeeTalk sebagai jembatan untuk memenuhi kebutuhan seksual, ekonomi, dan kebutuhan lainnya.

Interaksi yang terjadi antara PSK dengan pelanggan merupakan suatu fenomena yang nyata yang terjadi ditengah masyarakat sehari-hari. Meskipun tidak semua orang tau bentuk-bentuk interaksi ini, namun interaksi dan transaksi yang di perantarai oleh media BeeTalk ini terjadi disekitar kita. Ini merupakan realitas yang semakin lama semakin Nampak seiring dengan pesatnya kemajuan tekhnologi. Semakin canggi tekhnologi tersebut, maka akan semakin banyak cela untuk digunakan tidak sebagaimana mestinya.

\section{SIMPULAN}

Berdasarkan analisa dan hasil wawancara peneliti dengan para informan melalui beberapa media yang peneliti gunakan, ataupun bertemu secara langsung mengenai penggunaan aplikasi BeeTalk sebagai alat transaksi prostitusi secara online,dapat disimpulkan bahwa:

1. Pola komunikasi dalam transaksi prostitusi menggunakan aplikasi BeeTalk menggunakan pola komunikasi primer, sekunder dan sirkular hingga mencapai kesepakatan yang akan berlanjut pada kegiatan seksual hingga proses pembayaran.

2. Praktik prostitusi tidak hanya dilakukan dengan berhubungan intim, tapi juga ada bentuk-bentuk prostitusi lain yang dilakukan secara online seperti Video Call Sex (VCS) dan Phone Sex (PS). Bahkan dalam penelitian ditemukan pula praktik penipuan berkedok prostitusi yang dilakukan secara online menggunakan aplikasi BeeTalk.

3. Motivasi para pelaku prostitusi dalam menggunakan aplikasi BeeTalk sebagai alat transaksi prostitusi pada umumnya sama yaitu kemudahan mencari pemuas nafsu bagi para pelanggan dan 
kemudahan menjual jasa seks bagi para PSK yang didukung oleh fitur-fitur canggih dalam aplikasi BeeTalk, yang tidak dimiliki aplikasi lain yang dapat sehingga praktik transaksi prostitusi terjadi. Fitur-fitur tersebut dimanfaatkan para PSK untuk menjajakan jasa dan mengeksploitasi tubuh untuk menarik para pelanggan yang juga menggunakan aplikasi BeeTalk ini. Beberapa fitur juga dianggap memudahkan pengguna BeeTalk yang juga pelanggan untuk mencari PSK sesuai dengan kriteria yang dinginkan. Bahkan dalam penelitian ditemukan pula praktik penipuan berkedok prostitusi dengan memanfaatkan aplikasi BeeTalk itu sendiri.

\section{DAFTAR PUSTAKA}

\section{Buku}

Abraham, Francis, M. 1982. Modem Sociological Theory (An Introdaction) Oxford University Press. Chapter 8. Simbolic Interacsionism.

Abrar, Ana Nadhya. 2003. Tekhnologi Komunikasi: Perspektif Ilmu Komunikasi. Yogyakarta : LESFI.

Aukstakalnis, Steve dan Blatner, David, 1992. Silicon Mirage: The Art and Science of Virtual Reality, Peachpit, London. Bahfiarti, Tuti. 2012. Buku Ajar Teori - Teori Komunikasi. Makassar : Universitas Hasanuddin.

Baudrillard, Jean, 2004. Masyarakat konsumsi. Penerbit Kreasi Wacana. Yogyakarta. 1990. Seduction, St Martins Press. 2006, Ektasi Komunikasi. Penerbit Kreasi Wacana, Yogyakarta.

Brent D. Ruben Lea P. Stewart. 2014. Komunikasi dan Perilaku Manusia. Jakarta: Rajawali Pers.

Budiman, Kris,2011. Semiotika Visual; Konsep, isu, dan Problematika Ikonitas. Penerbit Jalasutra, Jogjakarta.

Cangara, Hafied, 2012. Pengantar Ilmu Komunikasi. : PT. Rajagrafindo Persada, Jakarta.

. 2014. Perencanaan dan Strategi Komunikasi. Depok : PT. Raja Grafindo Perkasa

Convelo G. Cevilla, dkk., 1993. Pengantar Metode Penelitian, Jakarta : Universitas Indonesia.

Daniluk, Judith C. 2013. Woman's Sexuality Across The Life Span. New York, London : The Guilford Press.

Denis McQuail. 1987. Mass Communication Theory. Secound Edition.

Devito Joseph A. 1997. Komunikasi Antar Manusia. Jakarta : Proffesionals Books

,2011. Komunikasi Antar Manusia. Tangerang Selatan :Karisma Publishing Group

Eriyanto. 2014. Analisis Jaringan Komunikasi. Jakarta: Prena Media Group.

Effendy, Onong. 2009. Ilmu Komunikasi Teori dan Praktek. Bandung :Rosdakarya

El Karimah, Kismiyati dan Wahyudin, Uud. 2010. Filsafat dan Etika Komunikasi :Bandung : Widya Padjajaran

Koentjoro. 2004. On The Spot: Tutur dari Seorang Pelacur. Yogyakarta: CV Qalams

Leary, Temothy, 1994. Chaos and Cyber-culture, Roning Publishing Inc.

Littlejohn, Stephen, 2009. Theories of Human Communication, Salemba Humanika, Jakarta.

McQuail Denis. 1996. Teori Komunikasi Massa Suatu Pengantar. Terjemahan Agus Dharma, Aminuddin Ram, PT Eblora Aksarana Pratama.

Moelong, Lexy.J .2009. Metode Penelitian Kualitatif. Bandung : PT. Remaja Rosdakarya.

Mulia, T.S G.E.T. AL. 1967. Pelacuran Ensiklopedia Indonesia. Bandung: N.VW Van Hoese.

Paul Martin, Lester. Dan Tovee, Martin, 2005. Upper Sadler River, NJ: Prentice Hall.

Puntoadi, Danis.2011.Menciptakan Penjualan Melalui Social Media.Jakarta: PT. Elex Media Komputindo

Purnama, Hadi. 2011. Media Sosial di Era Pemasaran 3.0.Corporate and Marketing Communication. Jakarta.

Rakhmad, Jalaludin. 2009. Metode Penelitian Komunikasi. Bandung : PT. Remaja Rosdakarya

Santoso, Edi dan Setiansah, Mite. 2009. Teori Komunikasi. Purwokerto : Graha Ilmu

Stephen W. Littlejohn dan Karen A.Foss, 2009, Theories of Human Communication, Jakarta Selatan: Salemba Humanika.

Sugiyono. 2010. Memamahami Penelitian Kualitatif. Bandung: Alfabeta .2012. Metode Penelitian Kuantitatif, Kualitatif, dan R\&D. Cetakan ke 17. Bandung : Alfabet

Sutarman, 2007, Cyber Crime Modus Operandi dan Penanggulangannya, LaksBang PRESSindo, Yogyakarta, hal. 67 Unde. Andi Alimuddin. 2014. Televisi \& Masyarakat Pluralistik. Jakarta: Prenada.

West, Richard and Turner, Lynn H. 2008. Pengantar Teori Komunikasi : Analisis dan Aplikasi. Jakarta : Salemba Humanika.

Wibowo, Wahyu. 2013. Kedaulatan Frekuensi Regulasi Penyiaran, Peran KPI, Dan Konvergensi Media. Jakarta: Kompas Media 
Wiryanto. 2004. Pengantar Ilmu Komunikasi. Jakarta : Grasindo

Yongky, Safanayong, 2006. Desain Komunikasi Visual Terpadu, Jakarta: Arte Median.

Zarrella, Dan, 2010.The Social Media Marketing Book. PT. Serambi Ilmu Semesta : Jakarta

\section{Website}

https://beetalkmobile.com/

https://beetalk.co.id/

https://www.kaskus.co.id/thread/570a09b896bde65d588b4570/kamus-prostitusi-online-ortu-kudu-baca/

https://makassar.terkini.id/warga-makassar-makin-kepincut-prostitusi-online-ini-aplikasi-yang-digunakan/ 2017)

https://makassar.terkini.id/aset/images/sites/2/2017/04/reddistrictgeylang.jpg (Agustus 2017)

http://sulsel.pojoksatu.id/read/2016/09/12/kenalan-di-beetalk-sekali-kencan-rp800-ribu-tapi-harus-di-hotel-yah/ (Agustus 2017)

http://ejournal.ilkom.fisip-unmul.ac.id/site/wp-content/uploads/2017/08/jurnal\%20fix\%20(08-01-17-02-27-00).pdf

http://detakriaunews.com/berita-yuk-kenali-istilah-bo-st-dan-lt-di-bisnis-prostitusi-online.html (september 2017)

http://www.viva.co.id/blog/teknologi/505688-semua-fitur-aplikasi-chatting-ada-di-beetalk

http://ahlikomunikasi.wordpress.com/2012/11/01/teori-media-baru

http://komunikasi.us/index.php/course/perkembangan-teknologi-komunikasi

http://www.ujungpandangekspres.com/view.php?id=26015

http://www.beritanet.com/Technology/Berita-IT/Situs-Sex-Internet.html

https://balianzahab.wordpress.com/cybercrime/modus-modus-kejahatan-dalam-teknologi-informasi/

\section{Disertasi, Tesis, Jurnal, Karya Ilmiah}

Alimuddin, Andi Battaria., Muhammad Najib. 2016. Sikap Dan Perilaku Remaja Perempuan Dalam Ajang Gaul Melalui Media Sosial Facebook The Attitude And Behavior Of Girl Adolescent In Social Media Facebook. Jurnal Ilmu Komunikasi. Program Pascasarjana Universitas Hasanuddin.

Andu, Christine Purnamasari. 2016. Penggunaan Media Grinder Dikalangan Gay Dalam Menjalin Hubungan Personal ( Suatu Studi Fenomenologi). Jurnal Ilmu Komunikasi. Program Pascasarjana Universitas Hasanuddin.

Api, Arleti Mochtar. 2015. Globalisasi Dan Dampaknya Telaah Kasus Pada Fenomena Telepon Genggam. Jurnal Telematika. Institut Tekhnologi Harapan Bangsa

Massyat, Muhammad., Hafied Cangara., Andi Alimuddin Unde. 2016. Media Baru Dan Transaksi Seksual; Studi Eksplorasi Pekerja Seks Komersil Terhadap Penggunaan Media Baru Di Kota Makassar. Jurnal Ilmu Komunikasi. Program Pascasarjana Universitas Hasanuddin.

Mukti, Imam., Muhammad Iqbal Sultan., Tuti Bahfiarti. 2016. Semiotika Ikon Perempuan Pada Iklan Mobil Dalam Majalah Otomotif Autoexpert. Jurnal Ilmu Komunikasi. Program Pasca Sarjana Universitas Hasanuddin.

Unde, Andi Alimuddin., Kenny Monica Kemal., Muhammad Najib. 2016. Semiotika Pesan Instagram Ani Yudhoyono Dalam Perspektif Etika Komunikasi. Jurnal Ilmu Komunikasi. Program Pascasarjana Universitas Hasanuddin. 